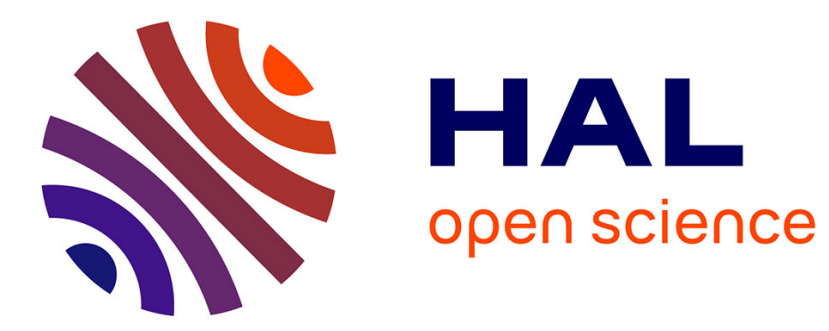

\title{
N-3 polyunsaturated fatty acid DHA during IVM affected oocyte developmental competence in cattle
}

Mouhamad Oseikria, Sébastien Elis, Virginie Maillard, Emilie Corbin, Svetlana Uzbekova

\section{- To cite this version:}

Mouhamad Oseikria, Sébastien Elis, Virginie Maillard, Emilie Corbin, Svetlana Uzbekova. N-3 polyunsaturated fatty acid DHA during IVM affected oocyte developmental competence in cattle. Theriogenology, 2016, 85 (9), pp.1625-1634. 10.1016/j.theriogenology.2016.01.019 . hal-01409334

\section{HAL Id: hal-01409334 \\ https://hal.science/hal-01409334}

Submitted on 5 Dec 2016

HAL is a multi-disciplinary open access archive for the deposit and dissemination of scientific research documents, whether they are published or not. The documents may come from teaching and research institutions in France or abroad, or from public or private research centers.
L'archive ouverte pluridisciplinaire HAL, est destinée au dépôt et à la diffusion de documents scientifiques de niveau recherche, publiés ou non, émanant des établissements d'enseignement et de recherche français ou étrangers, des laboratoires publics ou privés. 


\section{Accepted Manuscript}

N-3 polyunsaturated fatty acid DHA during IVM affected oocyte developmental competence in cattle

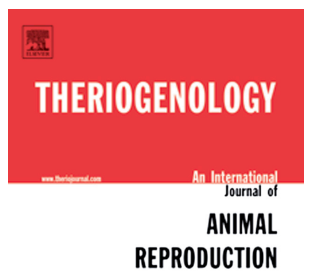

Mouhamad Oseikria, Sébastien Elis, Virginie Maillard, Emilie Corbin, Svetlana

Uzbekova

PII:

S0093-691X(16)00032-7

DOI:

10.1016/j.theriogenology.2016.01.019

Reference: THE 13487

To appear in: Theriogenology

Received Date: 20 October 2015

Revised Date: 19 January 2016

Accepted Date: 24 January 2016

Please cite this article as: Oseikria M, Elis S, Maillard V, Corbin E, Uzbekova S, N-3 polyunsaturated fatty acid DHA during IVM affected oocyte developmental competence in cattle, Theriogenology (2016), doi: 10.1016/j.theriogenology.2016.01.019.

This is a PDF file of an unedited manuscript that has been accepted for publication. As a service to our customers we are providing this early version of the manuscript. The manuscript will undergo copyediting, typesetting, and review of the resulting proof before it is published in its final form. Please note that during the production process errors may be discovered which could affect the content, and all legal disclaimers that apply to the journal pertain. 


\section{N-3 polyunsaturated fatty acid DHA during IVM affected oocyte}

4 developmental competence in cattle.

5 Mouhamad Oseikria ${ }^{1234}$, Sébastien Elis ${ }^{1234 \# \S}$, Virginie Maillard ${ }^{1234}$, Emilie Corbin ${ }^{1234}$,

6 Svetlana Uzbekova ${ }^{1234}$

$7{ }^{1}$ INRA, UMR85 Physiologie de la Reproduction et des Comportements, F-37380 Nouzilly, 8 France

92 CNRS, UMR 7247 Physiologie de la Reproduction et des Comportements, F-37380 10 Nouzilly, France

$11{ }^{3}$ Université François Rabelais de Tours, UMR Physiologie de la Reproduction et des 12 Comportements, F-37380 Nouzilly, France

$13{ }^{4}$ IFCE, UMR Physiologie de la Reproduction et des Comportements, F-37380 Nouzilly, 14 France

\# These authors contributed equally to this work

${ }^{\S}$ Corresponding author

Postal address: l'Orfrasière, 37380 Nouzilly, France

Email address:

$\underline{\text { Sebastien.Elis@tours.inra.fr }}$

Key words 


\section{ABSTRACT}

The positive effect of n-3 poly-unsaturated fatty acids (FA) on fertility in ruminants seems to be partly mediated through direct effects on the oocyte developmental potential. We aimed to investigate whether supplementation with physiological levels of docosahexaenoic acid (DHA, C22:6 n-3 PUFA) during in vitro maturation (IVM) has an effect on oocyte maturation and in vitro embryo development in cattle. We showed that DHA $(0,1,10$ or $100 \mu \mathrm{M})$ had no effect on oocyte viability or maturation rate after $22 \mathrm{~h}$ IVM. Incubation of oocyte-cumulus complexes (OCC) with $1 \mu \mathrm{M}$ DHA during IVM significantly increased $(\mathrm{p}<0.05)$ oocyte cleavage rate as compared to control $(86.1 \%$ vs. $78.8 \%$, respectively) and the $>4$-cell embryo rate at day 2 after parthenogenetic activation (PA) (39.1\% vs. 29.7\%, respectively). Supplementation with $1 \mu \mathrm{M}$ DHA during IVM also induced a significant increase in the blastocyst rate at day 7 after in vitro fertilization (IVF) as compared to control (30.6\% vs. $17.6 \%$, respectively) and tended to increase the number of cells in the blastocysts $(97.1 \pm 4.9$ vs. $81.2 \pm 5.3$, respectively; $\mathrm{p}=0.08$ ). On the contrary, $10 \mu \mathrm{M}$ DHA had no effects, whereas $100 \mu \mathrm{M}$ DHA significantly decreased the cleavage rate compared to control (69.5\% vs.78.8\%, respectively) and the $>4$-cell embryo rate at day 2 after PA (19.5\% vs. 29.7\%). As was shown by real-time PCR, negative effects of $100 \mu \mathrm{M}$ DHA were associated with significant increase of progesterone synthesis by OCCs, a three-fold increase in expression level of FA transporter CD36 and a two-fold decrease of FA synthase FASN genes in cumulus cells (CC) of corresponding oocytes. DHA at 1 and $10 \mu \mathrm{M}$ had no effect on expression of those and other key lipid metabolism-related genes in CC. In conclusion, administration of a low physiological dose of DHA $(1 \mu \mathrm{M})$ during IVM may have beneficial effects on oocyte developmental competence in vitro without affecting lipid metabolism gene expression in surrounding cumulus cells, contrarily to $100 \mu \mathrm{M}$ DHA which diminished oocyte quality associated with perturbation of lipid and steroid metabolism in CC. 


\section{INTRODUCTION}

52

Oocyte competence to develop into viable embryo after fertilization is mainly acquired during final oocyte growth and meiotic maturation. Fatty acids (FA) together with glucose and amino acids are an important source of energy for oocytes, as high amount of energy is required to perform meiosis [1]. Free FA, including non-esterified FA (NEFA), are present in both follicular fluid and in the oocyte-cumulus complex (OCC) and participate in formation of OCC follicular environment directly related to oocyte quality $[2,3]$. In fact, an oocyte, surrounded by cumulus cells (CC), is able to rapidly incorporate FA from maturation medium in vitro, as shown for oleic and linoleic acids $[4,5]$. The oocyte lipid content, in terms of FA composition, has been shown to influence oocyte maturation and developmental competence $[6,7]$. Moreover, the highest concentrations of NEFA in the OCC environment, in vivo and in vitro led to low oocyte quality and embryo developmental rate after in vitro fertilization (IVF) [8-10]. FA are essential to oocyte quality as energy source $[11,12]$, but in the case of elevated FA concentration in the environment (follicular fluid or maturation medium), CC are required to protect the oocyte by incorporating excessive FA and transforming them into storage droplets $[13,14]$. Moreover, during oocyte maturation CC ensure active lipid metabolism through modulation of expression of FA metabolism related genes [15].

N-3 polyunsaturated fatty acids (PUFA), namely, alpha-linolenic acid (ALA), eicosapentaenoic acid (EPA) and docosahexaenoic acid (DHA), belong to a family of biologically active FA and are known to have a variety of health benefits [16]. Mammals cannot produce the precursor of n-3 PUFA, ALA, which is thus considered essential FA. The longest member of this family, DHA, has a 22 carbon chain (C22:6) and can be produced by a series of desaturation and elongation reactions from shorter n-3 PUFA member such as ALA 
or EPA. Nevertheless, the most extensive source of DHA is the diet and particularly seafood.

DHA was also described as the most biologically active member of this family [17-19].

The n-3 PUFA exhibit a wide range of physiological roles in organism development and diseases [20], via receptors, sensors or cell membrane fatty acid composition (membrane order, lipid rafts, etc.) (reviewed in [21]). Among their physiological roles, n-3 PUFA have been reported to affect reproductive parameters in cattle [22, 23]. N-3 PUFA induce a reduction in prostaglandin $\mathrm{F} 2$ alpha $(\mathrm{PGF} 2 \alpha)$ secretion $[24,25]$, thus potentially providing a more favorable uterine environment [26]. Moreover, n-3 PUFA dietary supply in cows was reported to not only affect uterine environment but also to exert effects on the ovary [27]. Indeed, at the ovarian level, dietary n-3 PUFA leads to larger corpus luteum size and higher plasma progesterone levels $[28,29]$ and to increased number or size of follicles [30-32]. In addition, an n-3 PUFA-enriched diet has also led to an increased cleavage rate or a trend to increased blastocyst rate after in vivo maturation [31, 32]. Overall, the effects of such a diet on the conception rate are less clear [26]. However, an adequate n-3 PUFA dietary supply in dairy cows leads to a higher presumptive conception rate [30], or a tendency to an improved conception rate [33] and to a reduction in pregnancy loss [23, 28, 30]. However, in both dairy heifers and lactating cows, dietary n-3 PUFA had affected neither follicle numbers nor oocyte developmental potential and embryo quality [34, 35]. Moreover, potentially unfavorable effects of dietary n-3 PUFA on plasma progesterone level in dairy cows were reported [36]. These discrepancies in PUFA effects are likely due to differences in n-3 PUFA forms (rumen protected or unprotected) and/or doses of dietary supplementations suggesting a variety of effects depending on the concentrations used. Our recent study on n-3 PUFA dietary supplementation, given during postpartum period as a rumen-protected encapsulated fish oil, revealed a decrease in the non-fertilization or early embryo mortality rate in high milk production dairy cows as compared to n-6 PUFA supplementation; that suggested an effect of 
n-3 PUFA on oocyte quality in vivo [37]. Significant enrichment in DHA was confirmed in plasma of n-3 PUFA treated animals, thus it would be interesting to analyze the potential

101

102 103

104

105

106

107 beneficial effect of DHA at follicular level. Moreover, we showed in vitro that functionality of bovine follicular cells (cumulus and granulosa cells) is dependent on lipid metabolism [38, 39].

The first objective of the present study was to analyze whether supplementation with an n-3 PUFA, DHA, during in vitro maturation (IVM) of bovine oocytes may impact oocyte quality in terms of its competence to embryo development in vitro. The discrepancies of PUFA impacts from literature prompted us to investigate the effect of DHA concentrations, ranging from 1 to $100 \mu \mathrm{M}$ that either covers or overpasses physiological concentrations in follicular fluid and serum (1.5-15 $\mu \mathrm{M})$ [10]. We therefore performed DHA treatment only during IVM and then analyzed oocyte and CC viability, oocyte meiotic maturation and developmental competence through either parthenogenetic activation or in vitro fertilization (IVF). The second objective was to analyze whether lipid metabolism in $\mathrm{CC}$ was affected by DHA treatment and could explain its effect. We thus analyzed progesterone production and expression of lipid metabolism related genes in CC. 


\subsection{Ethics}

117 No experiments with living animals were performed.

\subsection{Chemicals}

120

121

122

123

124

All chemicals were purchased from Sigma-Aldrich (Saint-Quentin Fallavier, France) unless otherwise stated.

\subsection{Biological material}

Bovine immature OCC were retrieved from bovine ovaries collected at a commercial abattoir. Antral follicles from 3 to $6 \mathrm{~mm}$ in diameter were punctured using an $18 \mathrm{G}$ needle linked to a vacuum pump and to a $50 \mathrm{~mL}$ falcon tube. OCC with compact cumulus layers were selected and washed in TCM 199 HEPES medium complemented with $0.04 \%$ BSA and $25 \mu \mathrm{g} / \mathrm{mL}$ gentamycin.

\subsection{In vitro maturation (IVM)}

IVM was performed with groups of 50-60 OCC in $500 \mu \mathrm{L}$ of either serum-free TCM 199 complemented with EGF (10 ng/mL) and gentamycin $(10 \mu \mathrm{g} / \mathrm{mL})$ or TCM199 supplemented with $10 \%$ (v/v) FA-free fetal calf serum (FCS), EGF $(5 \mathrm{ng} / \mathrm{mL}), 17 \beta$-estradiol $(1 \mu \mathrm{g} / \mathrm{mL})$, FSH $(10 \mu \mathrm{g} / \mathrm{mL})$ and LH $(12 \mu \mathrm{g} / \mathrm{mL})$ (both Reprobiol, Lièges, Belgium), and gentamycin (5 $\mu \mathrm{g} / \mathrm{mL})$ in the presence or absence of DHA $(1 \mu \mathrm{M}, 10 \mu \mathrm{M}$ or $100 \mu \mathrm{M})$ at $38.8{ }^{\circ} \mathrm{C}$ in a humidified atmosphere containing $5 \% \mathrm{CO}_{2}$.

After 22 hours of IVM, CC were removed and both cells and spent IVM media were kept at $80^{\circ} \mathrm{C}$ until analysis. Oocytes were used either for analysis of meiotic maturation or for parthenogenetic activation (PA). 


\subsection{Analysis of cell viability.}

$\mathrm{CC}$ viability was assessed using the Bioluminescence Cytotoxicity Assay Kit (Medical and Biological Laboratories, Woburn, USA) to measure adenylate kinase activity in spent culture media according to the supplier's instructions. Adenylate kinase activity is correlated to the dead cell rate; its level was here normalized by the number of OCC in each well. Oocyte viability was assessed using the Live/Dead Viability/Cytotoxicity Kit for mammalian cells (Life Technologies, Cergy Pontoise, France) according to the supplier's instructions. Experiments were repeated five times with 50-60 OCC per conditions.

\subsection{Analysis of oocyte nuclear meiotic maturation stages.}

After 24 h IVM, oocytes were fixed in paraformaldehyde (4\% PFA in PBS 1x) and stained with Hoechst $33342(10 \mu \mathrm{g} / \mathrm{mL})$, allowing for the labeling of oocyte chromatin and thus the determination of its meiotic status, as detailed elsewhere [40]. Briefly, prophase oocytes at germinal vesicle $(\mathrm{GV}), \mathrm{GV}$ breakdown, metaphase-I and anaphase-I stages were considered as immature. The oocytes which had progressed to telophase-I or metaphase-II phases were considered as mature oocytes. Experiments were repeated three times with at least 50 oocytes per each IVM conditions per experiment.

\subsection{Parthenogenetic activation (PA)}

After 22 hours of IVM, CC were removed by pipette aspiration-ejections in the IVM media, centrifuged $5 \mathrm{~min}$ at $3500 \mathrm{~g}$, and both $\mathrm{CC}$ and spent media were kept at $-80^{\circ} \mathrm{C}$ until analysis. Before PA, denuded oocytes remained in the same IVM conditions for an additional 4 hours. Oocytes were then incubated $5 \mathrm{~min}$ in TCM199, ionomycin $5 \mu \mathrm{M}$, FA-free FCS $5 \%$, following by 4 hours in TCM199, 6-dimethylaminopurine (6-DMAP) 2 mM, FA-free FCS 5\%. In vitro development was performed in groups of 25 oocytes in a $25 \mu \mathrm{L}$ microdrop of 
mSOF (modified synthetic oviduct fluid supplemented with $1 \%$ estrus cow serum) under mineral oil at $38.8^{\circ} \mathrm{C}$ in a humidified atmosphere of $5 \% \mathrm{CO}_{2}, 5 \% \mathrm{O}_{2}$ and $90 \% \mathrm{~N}_{2}$ for seven days. The cleavage rate was assessed at day 2 post activation and embryo development was checked at day 7. Experiments were repeated five times with 50-60 OCC per each IVM conditions per experiment.

\subsection{In vitro fertilization (IVF)}

The mature OCC were transferred for washing in fertilization medium Fert-Talp [41]. Two straws per replicate of semen from the same ejaculate and/or bull were used throughout experiments. Motile sperm were separated by centrifugation (15 minutes at $700 \mathrm{~g}$ ) on $2 \mathrm{~mL}$ of Percoll (Pharmacia, Uppsala, Sweden) discontinuous density gradient (45\%/90\%). Viable sperm were diluted to $1.010^{6} \mathrm{sperm} / \mathrm{mL}$ in Fert-Talp medium. Sperm and OCC were then coincubated for 18 hours at $38.8 \mathrm{C}$ in a humidified atmosphere of $5 \% \mathrm{CO}_{2}$ in air. Then $\mathrm{CC}$ were removed, presumptive zygotes were washed and in vitro embryo development was performed in mSOF as described earlier (see section 2.7). The cleavage rate was assessed at day 2 after fertilization and embryo development was checked at day 7 post-IVF. Experiments were repeated three times with 50-60 OCC per each IVM conditions per experiment.

\subsection{Analysis of in vitro embryo development}

At day 2 of in vitro development (IVD), embryos were observed using a Zeiss inverted microscope (Zeiss, Germany) in order to count cell number in the cleaved embryos, and then in vitro culture was continued. This study being in the context of in vitro embryo production optimization, embryos were analyzed 7 days after the beginning of IVF (168 hours). All embryos were fixed in $4 \%$ paraformaldehyde and stained with Hoechst $33342(1 \mu \mathrm{g} / \mathrm{mL})$. The number of cells in each embryo was counted using an Axioplan Zeiss fluorescent microscope. 
Degraded embryos without visible chromatin staining were not taken into account. Blastocyst rate was defined as the total number of blastocysts reported to the number of cleaved embryos.

\subsection{Progesterone assay}

The progesterone concentration was determined in spent media after 22 hours of IVM in the presence or absence of DHA $(1,10$ or $100 \mu \mathrm{M})$ by using an enzyme-linked immunosorbent assay (ELISA) protocol as previously described [42]. For progesterone concentrations ranging from 0.4 to $10 \mathrm{ng} / \mathrm{mL}$, the intra-assay CVs averaged < 10\%. Progesterone secreted in each well was normalized to the number of maturing $\mathrm{OCC}$ in the same well. The results are presented as the amount of progesterone (ng) secreted per OCC, as means \pm SEM of five independent experiments.

\subsection{Gene expression analysis in $C C$}

Total RNA was extracted from CC using TriZol reagent (Invitrogen, Cergy Pontoise, France) following the manufacturer's instructions. RNA concentration was determined using a NanoDrop ND-1000 spectrophotometer (Nyxor Biotech, Paris, France). RNA preparations were DNAse digested by RQ1 DNase (Promega, Charbonnières, France) following the manufacturer's instructions. Reverse transcription (RT) was performed on $200 \mathrm{ng}$ of total RNA extracted from CC using Moloney Murine Leukemia Virus reverse transcriptase I (Invitrogen, Cergy Pontoise, France) with an oligo dT primer mix (Promega, Charbonnières, France) according to the manufacturer's instructions. Real-time PCR reactions were carried out on a MyiQ Cycler apparatus (Bio-Rad, Marnes la Coquette, France) in $20 \mu$ containing primers at a final concentration of $150 \mathrm{nM}$ of each, $5 \mu \mathrm{l}$ of the diluted RT reaction (1ng cDNA per reaction) and qPCR Mastermix Plus for Sybr Green I (Bio-Rad, Marnes-la-Coquette, 
215 France) according to the manufacturer's instructions. The efficiency of the primers and standard curve for each gene was deduced from serial dilutions of the correspondent cDNA

217 fragment obtained as a template (Table 1). The relative gene expression levels were calculated

218 in five independent $\mathrm{CC}$ samples for each condition. The geometric mean of three housekeeping genes (RPL19, RPS9 and GAPDH) was used to normalize gene expression. The relative amounts of gene transcripts (R) were calculated according to the equation:

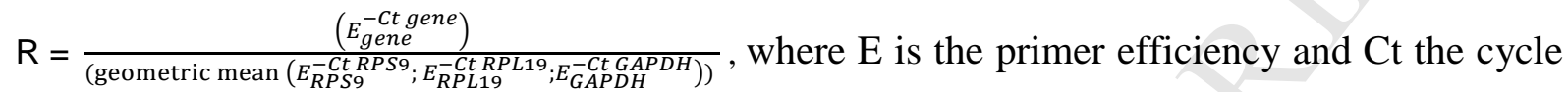
threshold. Five independent CC samples per condition were analyzed.

\subsection{Statistical analysis}

Statistical analyses taking into account both treatment effect and replica effect were performed for all parameters. The distribution of maturation stages, cleavage rates and blastocyst rates were compared by logistic regression analysis using generalized linear model (( $\mathrm{R}$ package Rcmdr, [43]), $\mathrm{R}$ version 3.2.1, [44]). Odds ratio and confidence intervals of the logistic regression analyses of oocyte maturation and development rates are provided in supplementary Table 1). Least square means (lsmeans) estimated by the models (R package 1smeans, [45]) were subsequently compared to the control conditions. Results are presented in tables and figures as lsmeans $\pm \mathrm{SEM}$, unless otherwise stated.

Number of blastocyst cells, CC viability, progesterone concentration and mRNA expression level were compared between the groups using either non-parametric one-way ANOVA, when four conditions were compared (R package lmPerm, [46]) with the Tukey post-hoc test (R package nparcomp, [47]), or Wilcoxon bivariate tests, when 2 conditions were compared (( $\mathrm{R}$ package coin, [48]), $\mathrm{R}$ version 3.2.1, [44]). A difference with $\mathrm{p} \leq 0.05$ was considered significant and with $0.05<\mathrm{p} \leq 0.10$ was considered a tendency. All p-values are given in Supplementary tables 1,2 , and 3. 


\section{RESULTS}

\subsection{In vitro development of oocytes after IVM with or without DHA}

243

In our experiments, OCC were matured in vitro with or without DHA $(1,10$, or $100 \mu \mathrm{M})$ and then in vitro embryo development was compared between conditions. We chose to assess oocyte developmental competence by using parthenogenetic activation (PA) first, because, in this case, embryo development only relies on oocyte maternal factors. DHA-treated and control oocytes underwent PA, and their cleavage rates were measured 40 hours later. As shown in Figure 1, $1 \mu \mathrm{M}$ DHA induced a significant $(\mathrm{p}<0.05)$ increase in the oocyte cleavage rate as compared to control $(86.1 \pm 2.1 \%$ vs. $78.8 \pm 2.5 \%$, respectively). On the contrary, 100 $\mu \mathrm{M}$ DHA induced a significant decrease in cleaved oocytes compared to control $(69.5 \pm 3.2 \%$ vs. $78.8 \pm 2.5 \%$, respectively). No difference was seen in the cleavage rate of the oocytes matured with DHA $10 \mu \mathrm{M}$. Cleaved embryos were differentiated as following: i) embryos exhibiting 2-4 cells or ii) embryos exhibiting more than 4 cells. No difference was reported in the $2-4$ cell embryo rate in the absence $(44.5 \pm 3.0 \%)$ or presence of $1 \mu \mathrm{M}$ DHA $(43.6 \pm$ $3.1 \%), 10 \mu \mathrm{M}(39.6 \pm 3.0 \%)$ or $100 \mu \mathrm{M}(44.6 \pm 3.4 \%)$. Concerning the embryos with more than 4 cells (>4-cell embryo), $1 \mu \mathrm{M}$ DHA induced a significant increase in the $>4$-cell embryo rate compared to the control group $(39.1 \pm 3.2 \%$ vs. $29.7 \pm 2.9 \%$, respectively). The same difference was observed in the $10 \mu \mathrm{M}$ DHA group, presenting a higher rate of > 4-cell embryos as compared to control (38.7 $\pm 3.2 \%$ vs. $29.7 \pm 2.9 \%$, respectively). On the contrary, $100 \mu \mathrm{M}$ DHA induced a significant decrease in the $>4$ cell embryo rate compared to control $(19.5 \pm 2.7 \%$ vs. $29.7 \pm 2.9 \%$, respectively). At day 7 of in vitro development, a rate of more than 16-cell embryos which had to undergo major activation of proper genome [49], was not different between $1 \mu \mathrm{M}$ DHA or $10 \mu \mathrm{M}$ DHA compared to control (34.1\%, 37.3\% and 40.0\%, 
264

265

266

267

268

269

270

271

272

273

274

275

276

277

278

279

280

281

282

283

284

285

286

287

respectively), but was significantly decreased at $100 \mu \mathrm{M}$ DHA (13.8\%) (Supplementary Table

1). Blastocyst rate was not different between control $(11.0 \pm 3.0 \%), 1 \mu \mathrm{M}$ DHA $(15.7 \pm 3.3 \%)$ and $10 \mu \mathrm{M}$ DHA $(10.7 \pm 2.8)$ groups. On the contrary, $100 \mu \mathrm{M}$ DHA tended to decrease blastocyst rate $(2.9 \pm 2.2 \%)$ compared to control ( $p<0.07)$. In the embryos that have reached blastocyst stage, no differences in cell number per blastocyst were found between control and any DHA group: $(58.1 \pm 5.1,67.2 \pm 5.6,60.5 \pm 3.4$, and $67.5 \pm 5.5$ cells per blastocyst in control, DHA1, DHA10, DHA100, respectively).

IVF was then performed to confirm our observations with PA on potentially better development of the oocytes matured in the presence of $1 \mu \mathrm{M}$ DHA (Figure 2A and supplementary Table 1). At day 2 after IVF, control and $1 \mu \mathrm{M}$ DHA groups showed no difference in the cleavage rate $(83.4 \pm 2.9$ vs. $85.0 \pm 2.8$, respectively), the $2-4$ cell embryo rate $(49.4 \pm 3.9$ vs. $49.8 \pm 3.9$, respectively) and the rate of embryos with more than 4 cells (33.2 \pm 3.6 vs. $34.0 \pm 3.7$, respectively). However, $1 \mu \mathrm{M}$ DHA led to a significant increase in the blastocyst rate at day 7 compared to control (30.6 \pm 4.1 vs. $17.6 \pm 3.3$, respectively). As shown in Figure 2B, the addition of $1 \mu \mathrm{M}$ DHA during IVM also tended to increase $(\mathrm{p}<0.08)$ the number of cells per blastocyst, as compared to control group $(97.1 \pm 4.9$ vs. $81.2 \pm 5.3$, respectively).

Therefore, supplement with $1 \mu \mathrm{M}$ DHA during IVM increased developmental capacity of treated oocytes as compared with control, $10 \mu \mathrm{M}$ had no effect, whereas $100 \mu \mathrm{M}$ DHA reduced embryo development rate.

\subsection{Effect of DHA on oocyte meiotic maturation}

Taking into account the effect of DHA on the cleavage rate, we aimed to determine whether oocyte nuclear maturation rate was affected by DHA. We thus performed $22 \mathrm{~h}$ IVM in the (9), 1625-1634. DOl : 10.1016/j.theriogenology.2016.01.019 
absence or presence of DHA $(1,10$ or $100 \mu \mathrm{M})$ added to the basic culture medium. No difference in the percentage of mature oocytes was found in the absence $(83.5 \pm 3.2 \%)$ or presence of DHA $(1 \mu \mathrm{M}(79.2 \pm 3.3 \%), 10 \mu \mathrm{M}(84.3 \pm 3.3 \%)$ or $100 \mu \mathrm{M}(84.7 \pm 3.6 \%))$. When comparing nuclear meiotic stages, no difference was reported in the ratio of immature, metaphase-I, anaphase-I and metaphase-II oocytes in the absence or presence of DHA $(1,10$ or $100 \mu \mathrm{M})$. When considering only telophase-I oocytes, a significant increase $(\mathrm{p}<0.05)$ was observed with $100 \mu \mathrm{M}$ DHA $(14.0 \pm 3.6 \%)$ compared to control $(5.0 \pm 1.9 \%)$ (Supplementary Table 2). Thus, addition of DHA during IVM (1, 10 or $100 \mu \mathrm{M})$ had no effect on the percentage of mature oocytes.

\subsection{Oocyte and cumulus cell viability in the presence or absence of DHA during IVM}

Oocyte viability showed no difference in terms of number of living oocytes after $22 \mathrm{~h} \mathrm{IVM} \mathrm{in}$ the absence or presence of $1,10,100 \mu \mathrm{M}$ DHA as compared with control $(98.8 \%, 97.0 \%$, 96.3 and 98.7, respectively). In order to investigate whether DHA affected cumulus functioning, the viability of $\mathrm{CC}$ was assessed by measuring adenylate kinase activity in spent culture media from corresponding OCC after IVM. No significant difference in adenylate kinase activity level was observed in the absence or presence of DHA $(874 \pm 44,868 \pm 47$, $948 \pm 40$ and $992 \pm 18$ relative light units for control, 1,10 and $100 \mu \mathrm{M}$ DHA, respectively). Thus, supplement with DHA during IVM affected neither oocytes nor surrounding CC viability.

\section{Gene expression in CC after 22 hours of IVM in the absence or presence of DHA}


In order to assess whether addition of DHA during IVM affects cellular lipid metabolism, relative expression of several candidate genes controlling the key steps of FA metabolism was measured in CC by real-time PCR and compared between the DHA-treated and control groups. The main processes of lipid metabolism and corresponding candidate genes are shown in Figure 3A. These include lipogenesis involving FA synthase (FASN) and diacylglycerol Oacyltransferase (DGAT1), FA transport (transporters $C D 36$, FA binding protein genes $F A B P 3$ and FABP5), lipolysis (phospholipase PNPLA2), lipid storage (perilipin PLIN2) and mitochondrial $\beta$-oxidation $(C P T 1 A, C P T 2)$. As shown in Figure 3B, $100 \mu \mathrm{M}$ DHA led to a significant two-fold decrease in FA synthase (FASN) expression and a tendency to increase FA transporter $C D 36$ expression in $\mathrm{CC}(\mathrm{p}=0.06)$ however lower DHA concentrations did not affect expression. The genes FABP3, DGAT1, PLIN2, CPT1A and CPT2 were similarly expressed in CC regardless of the DHA concentration during IVM (Supplementary table 3). We also analyzed the expression of PTGS2 gene involved in prostaglandin synthesis, and two other genes known to be affected by FA in other tissues : PPARG (transcription factor) and $N F K B$ (signaling pathway). None of these genes showed a change in expression in DHA treated CC (Supplementary table 3).

Thus, in CC, DHA at $1 \mu \mathrm{M}$ and $10 \mu \mathrm{M}$ had no effect on expression of candidate genes; FASN was only affected by the highest DHA concentration $(100 \mu \mathrm{M})$.

\section{Progesterone secretion by OCC in the presence or absence of DHA during IVM}

Progesterone secretion was measured in spent culture media after $22 \mathrm{~h} \mathrm{IVM} \mathrm{(Figure} \mathrm{4).} \mathrm{A}$ significant 2.2-fold increase in progesterone secretion was reported with only $100 \mu \mathrm{M}$ DHA compared to control $(\mathrm{p}<0.0001)$. No differences were observed with lower DHA concentrations as compared to control IVM without DHA. 


\section{DISCUSSION}

\section{DHA directly affects bovine oocyte quality}

336

337

In the present study, we analyzed the effect of addition of n-3 PUFA, DHA, during IVM culture, on oocyte developmental competence by following in vitro early embryo development in cattle. For the first time, we showed that the addition of a low physiological concentration of DHA (here, $1 \mu \mathrm{M}$ ) during IVM might improve oocyte proper competence to support embryo development.

In cattle, the concentration of DHA has been reported to be $5-15 \mu \mathrm{M}$ in serum and $1.5-3 \mu \mathrm{M}$ in follicular fluid from preovulatory dominant follicles [10]. Therefore, in the present study, DHA 1 and $10 \mu \mathrm{M}$ were physiological levels, contrary to DHA $100 \mu \mathrm{M}$. While in our study DHA was provided only during IVM, it should directly influence oocyte developmental potential acquired during maturation. Under these conditions, we observed a positive effect of a lower DHA concentration $(1 \mu \mathrm{M})$, no effect of DHA at $10 \mu \mathrm{M}$ and deleterious effect of 100 $\mu \mathrm{M}$ dose. Our results are in line with other in vitro data obtained in ruminants. Indeed, supplementation with $50 \mu \mathrm{M}$ ALA (a shorter member of the n-3 PUFA family) during IVM also led to increases in the cleavage rate, blastocyst rate and number of cells per embryo in bovine [50]. Moreover, $50 \mu \mathrm{M}$ ALA treatment during IVM also led to an increased number of cells in sheep embryos after in vitro development [51]. Interestingly, when DHA (1,10 or 100 $\mu \mathrm{M}$ ) was supplied during in vitro embryo development culture but not during IVM in cattle, no effect on cleavage rate was observed; however such treatment led to reduced blastocyst yield at day 7 when added at $10 \mu \mathrm{M}$ and reduced embryo survival at $100 \mu \mathrm{M}$ [52].

Our results on the effects of DHA are also relevant to in vivo experiments in ruminants. Indeed, an increased cell number was observed in blastocysts obtained in lactating dairy cows in vivo after increased n-3 PUFA dietary supply in cattle [53]. Moreover, after n-3 PUFA 
dietary supplementation of dairy cows, the cleavage rate of recovered oocytes was increased after IVM/IVF in the n-3 PUFA group and the blastocyst rate also tended to be higher, highlighting the role of n-3 PUFA on oocyte competence [31]. In addition, fish oil dietary supplementation (rich in EPA and DHA) improved oocyte quality also in sheep [54] and in dairy cows [37]. Taken together, all these data confirmed that n-3 PUFA could improve oocyte quality by acting during oocyte maturation or even before, i.e. during follicular growth. Nevertheless, a beneficial effect of n-3 PUFA on oocyte quality has not always been observed in vivo. Indeed, n-3 PUFA dietary supply did not improve in vivo embryo production after superovulation in dairy cows [29] or in vitro embryo production in dairy heifers [34]. These discrepancies between ruminant studies are likely due to differences in the form, dose, period and duration of n-3 PUFA supplementation between the experiments [55]. The PUFA may be differently oxidized, converted in other forms and largely degraded in the rumen [56] depending on the diet preparation. The absence of n-3 PUFA effects on oocyte competence in several studies could also be explained by the protective role of ovarian cells, which were able to absorb most of the lipids in order to protect the oocyte from the deleterious effects of PUFA excess [14, 57].

According to our in vitro data, direct contact of bovine OCC with DHA during 22 hours of IVM can affect oocyte ability to develop in vitro, and the lowest concentration of $1 \mu \mathrm{M}$ may have a beneficial effect on in vitro embryo production issues.

\section{When used at a high dose, DHA exhibits deleterious effects on oocyte quality}

As expected, a high dose of DHA had detrimental effect on developmental potential of bovine oocytes, nevertheless DHA did not impact their viability at the end of IVM. Indeed, addition of $100 \mu \mathrm{M}$ DHA during IVM significantly decreased the cleavage rate, the $>4$ cell embryo 
rate at day 2, and the rate of embryos with more than 16 cells at day 7 . Such embryos had already overcame major embryo genome activation (MGA) occurring at 8-16 cell stage [49], and their lower rate indicates that DHA excessive level $(100 \mu \mathrm{M})$ during IVM may have a deleterious effect on oocyte capacity to activate the factors involved in MGA and thus may lead to lower blastocyst rate. These results are relevant to the literature where high doses of n3 PUFA (100 and $200 \mu \mathrm{M}$ ALA) led to negative effects on oocyte maturation and the CC expansion rate in cattle [50] as well as in sheep [51]. Similarly, other PUFA exhibited the same lipotoxic effect at high doses; i.e. $100 \mu \mathrm{M}$ linoleic acid decreased the percentage of metaphase-II oocytes compared to lower doses $(9$ and $43 \mu \mathrm{M})$ and resulted in oocytes arrested at the immature state [5]. Therefore, when used at a high dose, the lipotoxic effects of n-3 PUFA resembled the effects of other FA. Indeed, palmitic acid $(150 \mu \mathrm{M})$ or stearic acid (75 $\mu \mathrm{M})$ added to bovine IVM media had negative effects on maturation, fertilization, cleavage rate and blastocyst yield $[2,58]$.

In the present study, $100 \mu \mathrm{M}$ DHA significantly increased progesterone secretion by OCC during IVM. Similarly, such an increase has been reported in sheep after treatment of OCC with $100 \mu \mathrm{M}$ ALA [51]. However, in sheep this increase in progesterone was not linked to an increase in oocyte or embryo quality. In our study, an increase in progesterone level secreted by OCC coincided with a decrease in blastocyst rate of corresponding oocytes. Indeed, in cattle, it has been shown that oocyte developmental competence was not related to progesterone levels in the follicular fluid [59]. Moreover, it was reported in cattle that although supplement with progesterone during IVM had no effect on the cleavage rate after IVF, the blastocyst rate rather decreased [60]. Therefore, the detrimental effect of $100 \mu \mathrm{M}$ DHA on oocyte developmental competence observed here could be partly due to modulations in CC steroid metabolism induced by this treatment. 
DHA modulates oocyte quality: what are the mechanisms?

408

409

410

411

412

413

414

415

416

417

418

419

420

421

422

423

424

425

426

427

428

429

430

431

The present study demonstrated that the impact of DHA on oocyte competence to develop was not due to the modulation of meiotic maturation. Indeed, here no differences in maturation rate were reported after any DHA treatment as compared to control, except a slower transition from telophase to metaphase-II in DHA $100 \mu \mathrm{M}$ treated oocytes. The discrepancies of n-3 PUFA effect on oocyte maturation occurred also in the literature. Indeed, supplementation with another n-3 PUFA, ALA, at $50 \mu \mathrm{M}$ during IVM increased the rate of metaphase-II oocytes in cattle [50]. In contrast, ALA used during IVM at 50 and $100 \mu \mathrm{M}$ did not affect nuclear maturation in sheep, and at $200 \mu \mathrm{M}$ reduced the maturation rate [51]. In addition, in cattle, when used in vivo, ALA also had no effect on oocyte nuclear maturation [35]. Other n-6 PUFA, linoleic acid, have also been reported to exhibit either no effect [5] or an inhibitory effect [61] on nuclear maturation in cows. These results are in line with ours, as we did not find any effect on nuclear maturation in DHA $1 \mu \mathrm{M}$ and $10 \mu \mathrm{M}$ groups.

Taken together, all these studies and our results inferred that not nuclear maturation but cytoplasm maturation might be affected in oocyte as a result of DHA supply during IVM. Cytoplasm maturation includes accumulation of maternal factors, such as transcripts, proteins and energy storage which are used to support the first cleavages. Cumulus cells play an important role in cytoplasm maturation of oocytes by regulating energy metabolism inside the OCC during maturation [62], and the role of lipid metabolism in CC for oocyte maturation revealed to be important $[11,15,63]$. Addition of DHA in IVM medium was thought to modulate lipid metabolism in OCC and thus be linked to modulation of oocyte quality. Indeed, we investigated the expression of candidate genes from several key lipid metabolism functions: lipogenesis $(F A S N)$, lipid storage (DGAT1), lipolysis (PLIN2, PNPLA2), FA incorporation $(C D 36)$ and transport $(F A B P 3, F A B P 5)$, and FA $\beta$-oxidation $(C P T 1 A, C P T 2)$ [64]. While expression was not changed in $1 \mu \mathrm{M}$ DHA-treated and control CC, none of these (9), 1625-1634. DOl : 10.1016/j.theriogenology.2016.01.019 
432

433

434

435

436

437

438

439

440

441

442

443

444

445

446

447

448

449

450

451

452

453

454

455

456

genes seemed to be involved in the beneficial effect of low DHA concentration on oocyte quality, and therefore lipid metabolism functions might not be critical to promote DHA effects. In contrast, the lipotoxic effect of DHA $100 \mu \mathrm{M}$ was relevant to the regulation of gene expression in $\mathrm{CC}$, as reported in the present study, and to the protective role of $\mathrm{CC}$ for oocytes against excess of FA in environment [14]. Indeed we observed an increased mRNA expression of CD36 in CC treated with $100 \mu \mathrm{M}$ DHA. CD36 is responsible of FA incorporation from the extracellular environment [65], and CC protect oocytes from increased free FA levels by massive intracellular lipid storage, this may safeguard the oocyte from lipotoxic effects [14]. Therefore, an increase in the extracellular free FA concentration could up-regulate $C D 36$ expression in order to increase FA intracellular incorporation in $\mathrm{CC}$, thus protecting the oocyte. Consequently, an increase in the amount of intracellular free FA would down-regulate FASN expression, as was here observed in $\mathrm{CC}$, and consequently this may decrease lipogenesis similarly to what was reported in mammary gland [66].

DHA may act in several other ways, as it has been reported, to be able to bind transcription factors such as peroxisome proliferator-activated receptor $\gamma$ and $\alpha$ (PPARG and PPARA) and consequently improve insulin sensitivity in adipocytes [67]. $N F K B$ was also reported to be increased in adipocytes in vivo after DHA supplementation [68] and to be able to interact with PPARG and to lead to a decrease in PTGS2 (alias COX2) expression [67]. In our study, expression of PPARG, NFKB and PTGS2 was detected in CC, however it did not differ between DHA-treated and control CC, indicating that DHA at the studied doses might not impact mRNA level of these genes. Nevertheless, these factors may act on protein level, being post-translationally modified. Although prostaglandin synthesis in CC does not seem to be affected by DHA in our conditions, n-3 PUFA could decrease eicosanoid production (prostaglandins, thromboxanes, leukotrienes) and can therefore affect cells by regulating these mediators [21]. 
457 N-3 PUFA can also bind to surface or intracellular FA receptors or sensors. DHA has been

458 already reported to be able to bind G protein coupled surface receptors such as free fatty acid 459 receptors, thus activating their signaling pathways [21]. In addition, DHA can also affect cells 460 via changes in the composition of cell membrane phospholipids. Indeed, FA in cell membrane 461 can affect protein function by modifying membrane fluidity and lipid raft formation [69]. 462 Lipid rafts appear to act as signaling platforms, as many proteins involved in signal 463 transduction are mostly found in lipid rafts [70], and long-chain n-3 PUFA seem to influence 464 raft formation and function [71]. These mechanisms are not yet investigated in $\mathrm{CC}$ and in oocyte and might be considered for further analysis.

\section{Conclusion}

In the present study, we have investigated the effect of an n-3 PUFA, DHA, on bovine oocyte quality in vitro, by supplementing IVM medium with DHA and assessing both meiotic maturation and embryo development after parthenogenetic activation or IVF. Without effect on meiotic maturation, DHA at $1 \mu \mathrm{M}$ could increase embryo development rate in vitro and cell number in blastocysts. Such improvement of oocyte developmental quality might be related to oocyte cytoplasm maturation, even if $\mathrm{CC}$ gene expression study did not manage to highlight involvement of lipid metabolism in DHA mechanism of action. In contrast, negative effect of $100 \mu \mathrm{M}$ DHA on oocyte quality seemed to be related to fatty acid and steroid metabolism perturbations in CC. Further studies are needed to elucidate the mechanisms and pathways in CC involved in the beneficial effects of DHA on oocyte competence. 
482 The authors declare that there are no conflicts of interest that could be perceived as 483 prejudicing the impartiality of the research reported.

484

485 FUNDING

486 This work was financially supported by l'Institut National de la Recherche Agronomique and 487 by Région Centre “Bovoméga3 proposal'. The funders had no role in study design, data 488 collection and analysis, decision to publish, or preparation of the manuscript.

489

490 ACKNOWLEDGMENTS

491 We would like to thank the technical staff of the laboratory, as well as Albert Arnould, Jean492 Noel Couet, Thierry Delpuech and Gaël Ramé for providing ovaries from the slaughterhouse.

493

494 
496

497

498

499

500

501

502

503

504

505

506

507

508

509

510

511

512

513

514

515

516

517

518

519

520

521

522

523

524

525

526

527

528

529

530

531

532

533

534

535

536

537

538

539

540

541

542

[1] Sturmey RG, Reis A, Leese HJ, McEvoy TG. Role of fatty acids in energy provision during oocyte maturation and early embryo development. Reproduction in Domestic Animals. 2009;44 Suppl 3:50-8.

[2] Leroy JL, Vanholder T, Mateusen B, Christophe A, Opsomer G, de Kruif A, et al. Non-esterified fatty acids in follicular fluid of dairy cows and their effect on developmental capacity of bovine oocytes in vitro. Reproduction. 2005;130:485-95.

[3] Zeron Y, Ocheretny A, Kedar O, Borochov A, Sklan D, Arav A. Seasonal changes in bovine fertility: relation to developmental competence of oocytes, membrane properties and fatty acid composition of follicles. Reproduction. 2001;121:447-54.

[4] Aardema H, Vos PL, Lolicato F, Roelen BA, Knijn HM, Vaandrager AB, et al. Oleic acid prevents detrimental effects of saturated fatty acids on bovine oocyte developmental competence. Biology of Reproduction. 2011;85:62-9.

[5] Carro M, Buschiazzo J, Rios GL, Oresti GM, Alberio RH. Linoleic acid stimulates neutral lipid accumulation in lipid droplets of maturing bovine oocytes. Theriogenology. 2013;79:687-94.

[6] Kim JY, Kinoshita M, Ohnishi M, Fukui Y. Lipid and fatty acid analysis of fresh and frozenthawed immature and in vitro matured bovine oocytes. Reproduction. 2001;122:131-8.

[7] Castaneda CA, Kaye P, Pantaleon M, Phillips N, Norman S, Fry R, et al. Lipid content, active mitochondria and brilliant cresyl blue staining in bovine oocytes. Theriogenology. 2013;79:417-22.

[8] Jorritsma R, César ML, Hermans JT, Kruitwagen CLJ, Vos PLAM, Kruip TAM. Effects of nonesterified fatty acids on bovine granulosa cells and developmental potential of oocytes in vitro. Animal Reproduction Science. 2004;81:225-35.

[9] Van Hoeck V, Leroy JL, Arias-Alvarez M, Rizos D, Gutierrez-Adan A, Schnorbusch K, et al. Oocyte developmental failure in response to elevated non-esterified fatty acid concentrations: mechanistic insights. Reproduction. 2013.

[10] Bender K, Walsh S, Evans ACO, Fair T, Brennan L. Metabolite concentrations in follicular fluid may explain differences in fertility between heifers and lactating cows. Reproduction. 2010;139:1047-55.

[11] Auclair S, Uzbekov R, Elis S, Sanchez L, Kireev I, Lardic L, et al. Absence of cumulus cells during in vitro maturation affects lipid metabolism in bovine oocytes. American Journal of Physiology Endocrinology and Metabolism. 2013;304:E599-E613.

[12] Prates EG, Nunes JT, Pereira RM. A role of lipid metabolism during cumulus-oocyte complex maturation: impact of lipid modulators to improve embryo production. Mediators of Inflammation. 2014;2014:692067.

[13] Lolicato F, Brouwers JF, de Lest CH, Wubbolts R, Aardema H, Priore P, et al. The cumulus cell layer protects the bovine maturing oocyte against fatty acid-induced lipotoxicity. Biology of Reproduction. 2015;92:16.

[14] Aardema H, Lolicato F, van de Lest CHA, Brouwers JF, Vaandrager AB, van Tol HTA, et al. Bovine cumulus cells protect maturing oocytes from increased fatty acid levels by massive intracellular lipid storage. Biology of Reproduction. 2013;88:164, 1-15.

[15] Sanchez-Lazo L, Brisard D, Elis S, Maillard V, Uzbekov R, Labas V, et al. Fatty acid synthesis and oxidation in cumulus cells support oocyte maturation in bovine. Molecular Endocrinology. 2014;28:1502-21.

[16] Siriwardhana N, Kalupahana NS, Moustaid-Moussa N. Chapter 13 - Health Benefits of $n-3$ Polyunsaturated Fatty Acids: Eicosapentaenoic Acid and Docosahexaenoic Acid. In: Se-Kwon K, editor. Advances in Food and Nutrition Research: Academic Press; 2012. p. 211-22.

[17] Simopoulos AP. Omega-3 fatty acids in inflammation and autoimmune diseases. Journal of the American College of Nutrition. 2002;21:495-505. 
[18] Plourde M, Cunnane SC. Extremely limited synthesis of long chain polyunsaturates in adults: implications for their dietary essentiality and use as supplements. Applied Physiology, Nutrition, and Metabolism. 2007;32:619-34.

[19] Deckelbaum RJ, Torrejon C. The omega-3 fatty acid nutritional landscape: health benefits and sources. Journal of Nutrition. 2012;142:587S-91S.

[20] Riediger ND, Othman RA, Suh M, Moghadasian MH. A systemic review of the roles of $n-3$ fatty acids in health and disease. Journal of the American Dietetic Association. 2009;109:668-79.

[21] Calder PC. Mechanisms of action of (n-3) fatty acids. Journal of Nutrition. 2012;142:592S-9S.

[22] Cerri RL, Juchem SO, Chebel RC, Rutigliano HM, Bruno RG, Galvao KN, et al. Effect of fat source differing in fatty acid profile on metabolic parameters, fertilization, and embryo quality in highproducing dairy cows. Journal of Dairy Science. 2009;92:1520-31.

[23] Santos JE, Bilby TR, Thatcher WW, Staples CR, Silvestre FT. Long chain fatty acids of diet as factors influencing reproduction in cattle. Reproduction in Domestic Animals. 2008;43 Suppl 2:2330.

[24] Mattos R, Staples CR, Arteche A, Wiltbank MC, Diaz FJ, Jenkins TC, et al. The effects of feeding fish oil on uterine secretion of PGF2alpha, milk composition, and metabolic status of periparturient Holstein cows. Journal of Dairy Science. 2004;87:921-32.

[25] Caldari-Torres C, Rodriguez-Sallaberry C, Greene ES, Badinga L. Differential effects of $n-3$ and $\mathrm{n}-6$ fatty acids on prostaglandin F2[alpha] production by bovine endometrial cells. Journal of Dairy Science. 2006;89:971-7.

[26] Gulliver CE, Friend MA, King BJ, Clayton EH. The role of omega-3 polyunsaturated fatty acids in reproduction of sheep and cattle. Animal Reproduction Science. 2012;131:9-22.

[27] Robinson RS, Pushpakumara PG, Cheng Z, Peters AR, Abayasekara DR, Wathes DC. Effects of dietary polyunsaturated fatty acids on ovarian and uterine function in lactating dairy cows. Reproduction. 2002;124:119-31.

[28] Petit HV, Twagiramungu H. Conception rate and reproductive function of dairy cows fed different fat sources. Theriogenology. 2006;66:1316-24.

[29] Childs S, Carter F, Lynch CO, Sreenan JM, Lonergan P, Hennessy AA, et al. Embryo yield and quality following dietary supplementation of beef heifers with $n-3$ polyunsaturated fatty acids (PUFA). Theriogenology. 2008;70:992-1003.

[30] Ambrose DJ, Kastelic JP, Corbett R, Pitney PA, Petit HV, Small JA, et al. Lower pregnancy losses in lactating dairy cows fed a diet enriched in alpha-linolenic acid. Journal of Dairy Science. 2006;89:3066-74.

[31] Moallem U, Shafran A, Zachut M, Dekel I, Portnick Y, Arieli A. Dietary alpha-linolenic acid from flaxseed oil improved folliculogenesis and IVF performance in dairy cows, similar to eicosapentaenoic and docosahexaenoic acids from fish oil. Reproduction. 2013;146:603-14.

[32] Zachut M, Dekel I, Lehrer H, Arieli A, Arav A, Livshitz L, et al. Effects of dietary fats differing in $\mathrm{n}-6: \mathrm{n}-3$ ratio fed to high-yielding dairy cows on fatty acid composition of ovarian compartments, follicular status, and oocyte quality. Journal of Dairy Science. 2010;93:529-45.

[33] Dirandeh E, Towhidi A, Zeinoaldini S, Ganjkhanlou M, Ansari Pirsaraei Z, Fouladi-Nashta A. Effects of different polyunsaturated fatty acid supplementations during the postpartum periods of early lactating dairy cows on milk yield, metabolic responses, and reproductive performances. Journal of Animal Science. 2013;91:713-21.

[34] Ponter AA, Guyader-Joly C, Nuttinck F, Grimard B, Humblot P. Oocyte and embryo production and quality after OPU-IVF in dairy heifers given diets varying in their $n-6 / n-3$ fatty acid ratio. Theriogenology. 2012;78:632-45.

[35] Bilby TR, Block J, do Amaral BC, Sa Filho O, Silvestre FT, Hansen PJ, et al. Effects of dietary unsaturated fatty acids on oocyte quality and follicular development in lactating dairy cows in summer. Journal of Dairy Science. 2006;89:3891-903.

[36] Hutchinson IA, Hennessy AA, Waters SM, Dewhurst RJ, Evans ACO, Lonergan P, et al. Effect of supplementation with different fat sources on the mechanisms involved in reproductive performance in lactating dairy cattle. Theriogenology. 2012;78:12-27. 
[37] Elis S, Freret S, Desmarchais A, Maillard V, Cognié J, Briant E, et al. Effect of a long chain n-3 PUFA-enriched diet on production and reproduction variables in Holstein dairy cows. Anim Reprod Sci. 2016;164:121-32.

[38] Sanchez-Lazo L, Brisard D, Elis S, Maillard V, Uzbekov R, Labas V, et al. Fatty acid synthesis and oxidation in cumulus cells support oocyte maturation in bovine. Mol Endocrinol. 2014;28:1502-21.

[39] Elis S, Desmarchais A, Maillard V, Uzbekova S, Monget P, Dupont J. Cell proliferation and progesterone synthesis depend on lipid metabolism in bovine granulosa cells. Theriogenology. 2015;83:840-53.

[40] Brisard D, Desmarchais A, Touze JL, Lardic L, Freret S, Elis S, et al. Alteration of energy metabolism gene expression in cumulus cells affects oocyte maturation via MOS-mitogenactivated protein kinase pathway in dairy cows with an unfavorable "Fertil-" haplotype of one female fertility quantitative trait locus. Theriogenology. 2014;81:599-612.

[41] Parrish JJ, Susko-Parrish J, Winer MA, First NL. Capacitation of bovine sperm by heparin. Biology of Reproduction. 1988;38:1171-80.

[42] Canepa S, Laine A, Bluteau A, Fagu C, Flon C, Monniaux D. Validation d'une methode immunoenzymatique pour le dosage de la progesterone dans le plasma des ovins et des bovins. Les Cahiers Techniques de L'INRA. 2008;64:19-30.

[43] Fox J. The R Commander: A Basic-Statistics Graphical User Interface to R. 2005. 2005;14:42.

[44] R_Core_Team. R: a language and environment for statistical computing. Vienna, Austria2015. [45] Lenth RV, Hervé M. Package "Ismeans". 2015.

[46] Wheeler B. ImPerm: Permutation tests for linear models. 2010.

[47] Konietschke F, Placzek M, Schaarschmidt F, Hothorn LA. nparcomp: an R software package for nonparametric multiple comparisons and simultaneous confidence intervals. Journal of Statistical Software. 2015;64:1-17.

[48] Hothorn T, Hornik K, van de Wiel MA, Zeileis A. Implementing a Class of Permutation Tests: The coin Package. 2008. 2008;28:23.

[49] Graf A, Krebs S, Heininen-Brown M, Zakhartchenko V, Blum H, Wolf E. Genome activation in bovine embryos: review of the literature and new insights from RNA sequencing experiments. Anim Reprod Sci. 2014;149:46-58.

[50] Marei WF, Wathes DC, Fouladi-Nashta AA. The effect of linolenic acid on bovine oocyte maturation and development. Biology of Reproduction. 2009;81:1064-72.

[51] Ghaffarilaleh V, Fouladi-Nashta A, Paramio MT. Effect of alpha-linolenic acid on oocyte maturation and embryo development of prepubertal sheep oocytes. Theriogenology. 2014;82:68696.

[52] Al Darwich A, Perreau C, Petit MH, Papillier P, Dupont J, Guillaume D, et al. Effect of PUFA on embryo cryoresistance, gene expression and AMPKalpha phosphorylation in IVF-derived bovine embryos. Prostaglandins \& Other Lipid Mediators. 2010;93:30-6.

[53] Thangavelu G, Colazo MG, Ambrose DJ, Oba M, Okine EK, Dyck MK. Diets enriched in unsaturated fatty acids enhance early embryonic development in lactating Holstein cows. Theriogenology. 2007;68:949-57.

[54] Zeron Y, Sklan D, Arav A. Effect of polyunsaturated fatty acid supplementation on biophysical parameters and chilling sensitivity of ewe oocytes. Molecular Reproduction and Development. 2002;61:271-8.

[55] Leroy J, Sturmey RG, Van Hoeck V, De Bie J, McKeegan PJ, Bols PEJ. Dietary fat supplementation and the consequences for oocyte and embryo quality: hype or significant benefit for dairy cow reproduction? Reproduction in Domestic Animals. 2014;49:353-61.

[56] Gruffat D, Gobert M, Durand D, Bauchart D. Distinct metabolism of linoleic and linolenic acids in liver and adipose tissues of finishing Normande cull cows. Animal. 2011;5:1090-8.

[57] Fouladi-Nashta AA, Wonnacott KE, Gutierrez CG, Gong JG, Sinclair KD, Garnsworthy PC, et al. Oocyte quality in lactating dairy cows fed on high levels of $n-3$ and $n-6$ fatty acids. Reproduction. 2009;138:771-81. 
[58] Van Hoeck V, Sturmey RG, Bermejo-Alvarez P, Rizos D, Gutierrez-Adan A, Leese HJ, et al. Elevated non-esterified fatty acid concentrations during bovine oocyte maturation compromise early embryo physiology. PLoS One. 2011;6:e23183.

[59] Matoba S, Bender K, Fahey AG, Mamo S, Brennan L, Lonergan P, et al. Predictive value of bovine follicular components as markers of oocyte developmental potential. Reproduction Fertility and Development. 2014;26:337-45.

[60] Silva CC, Knight PG. Effects of androgens, progesterone and their antagonists on the developmental competence of in vitro matured bovine oocytes. Journal of Reproduction and Fertility. 2000;119:261-9.

[61] Marei WF, Wathes DC, Fouladi-Nashta AA. Impact of linoleic acid on bovine oocyte maturation and embryo development. Reproduction. 2010;139:979-88.

[62] Songsasen N, Comizzoli P, Nagashima J, Fujihara M, Wildt DE. The Domestic Dog and Cat as Models for Understanding the Regulation of Ovarian Follicle Development In Vitro. Reprod Domest Anim. 2012;47:13-8.

[63] Prates EG, Nunes JT, Pereira RM. A role of lipid metabolism during cumulus-oocyte complex maturation: impact of lipid modulators to improve embryo production. Mediators Inflamm. 2014;2014:692067.

[64] Ruggles KV, Turkish A, Sturley SL. Making, baking, and breaking: the synthesis, storage, and hydrolysis of neutral lipids. Annual Review of Nutrition. 2013;33:413-51.

[65] Carley AN, Kleinfeld AM. Fatty acid (FFA) transport in cardiomyocytes revealed by imaging unbound FFA is mediated by an FFA pump modulated by the CD36 protein. Journal of Biological Chemistry. 2011;286:4589-97.

[66] Angulo J, Mahecha L, Nuernberg K, Nuernberg G, Dannenberger D, Olivera M, et al. Effects of polyunsaturated fatty acids from plant oils and algae on milk fat yield and composition are associated with mammary lipogenic and SREBF1 gene expression. Animal. 2012;6:1961-72.

[67] Calder PC. Mechanisms of action of ( $n-3)$ fatty acids. J Nutr. 2012;142:592S-9S.

[68] Schmitt E, Ballou MA, Correa MN, DePeters EJ, Drackley JK, Loor JJ. Dietary lipid during the transition period to manipulate subcutaneous adipose tissue peroxisome proliferator-activated receptor-î̉ co-regulator and target gene expression. J Dairy Sci. 2011;94:5913-25.

[69] Calder PC. Fatty acids and inflammation: the cutting edge between food and pharma. European Journal of Pharmacology. 2011;668 Suppl 1:S50-8.

[70] Pike L. Lipid rafts: bringing order to chaos. Journal of Lipid Research. 2003;44:655-67.

[71] Shaikh SR, Rockett BD, Salameh M, Carraway K. Docosahexaenoic acid modifies the clustering and size of lipid rafts and the lateral organization and surface expression of MHC class I of EL4 cells. Journal of Nutrition. 2009;139:1632-9. 
686

687

688

689

690

691

692

693

694

695

696

697

698

699

700

701

702

703

704

705

706

707

708

709

Figure legends

Figure 1: Effect of DHA during IVM on cleavage rate at day 2 and blastocyst rate at day 7 after parthenogenetic activation

Embryo cleavage and blastocyst rates in control and DHA-treated groups $(1,10$ and $100 \mu \mathrm{M})$ were assessed 2 days and 7 days after PA, respectively. Among the cleaved oocytes, embryos $>4$ cell stage were distinguished. Percentage of blastocysts was reported to the number of cleaved embryos at day 2. Results of five independent experiments are expressed as the lsmeans percentage of embryos in each developmental stage \pm SEM. * indicates a significant difference for a given stage compared to the control $(p<0.05)$. \# indicates a tendency of a difference compared to the control $(0.05<p<0.1)$. Total numbers of analyzed parthenogenetically activated oocytes per group are shown between brackets.

\section{Figure 2: Effect of $1 \mu$ M DHA during IVM on embryo development after IVF.}

A. Embryo cleavage and blastocyst rates in control and DHA-treated groups $(1 \mu \mathrm{M})$ were assessed 2 days and 7 days after IVF, respectively. Among the cleaved oocytes, embryos $>4$ cell stage were distinguished. Percentage of blastocysts was reported to the number of cleaved embryos at day 2. Results of three independent experiments are expressed as the lsmeans percentage of embryos in each developmental stage \pm SEM or as the mean blastocyst cell number \pm SEM. * indicates a significant difference for a given stage compared to the control $(p<0.05)$. Total numbers of analyzed in vitro fertilized oocytes per group are shown between brackets. B. Number of cells (mean \pm SEM) in the blastocysts developed from the oocytes treated or not with DHA $1 \mu \mathrm{M}$ during IVM. \# indicates a tendency of a difference $(0.05<\mathrm{p}<$ 0.1) compared to control. 


\section{ACCEPTED MANUSCRIPT}

Figure 3: Analysis of lipid metabolism related genes in $\mathrm{CC}$ after DHA treatment during IVM.

A. Scheme of disposition of genes involved in lipid metabolism main processes (grey boxes) according to their known functions in different cells, which were analyzed in CC treated with 0,1, 10 and $100 \mu \mathrm{M}$ DHA. Abbreviations: FA: fatty acids. Genes: FASN : fatty acid synthase, FABP3 and FABP5: fatty acids binding proteins 3 and 5, DGAT1 : Diacylglycerol Oacyltransferase 1, PNPLA2: Patatin-like phospholipase domain containing 2, PLIN2: periline 2, CPT1: carnitine palmitoyl transferase 1, CPT2: carnitine palmitoyl transferase 2, CD36: thrombospondin receptor, FA transporter. B. Relative expression of $C D 36$ and FASN genes in $\mathrm{CC}$ after $22 \mathrm{~h}$ IVM measured by real time PCR. The geometric mean of three housekeeping genes (RPL19, RPS9 and GAPDH) was used to normalize gene expression. Results of five independent cultures with each condition in duplicate are presented as means \pm SEM. * indicates significant difference for a given stage compared to the control $(p<0.05)$. \# indicates a tendency of a difference $(0.05<\mathrm{p}<0.1)$ compared to the control. Other genes showed no difference between DHA-treated and control CC.

Figure 4: Effect of DHA on progesterone secretion level by oocyte-cumulus complexes after 22h IVM

Progesterone concentration value was normalized by the number of OCC in each well. The data are expressed as ng of progesterone secreted per OCC. Results of five independent experiments are presented as means \pm SEM. * indicates a significant difference for a given stage compared to the control $(p<0.05)$. 
Tables :

Table 1: Oligonucleotide sequences

\begin{tabular}{|c|c|c|c|c|c|c|}
\hline Abbrev. & $\begin{array}{l}\text { Accession } \\
\text { number }\end{array}$ & Gene & Forward primer & Reverse primer & bp & $\mathrm{E}$ \\
\hline CD36 & BC103112.1 & thrombospondin receptor & GCATTCTGAAAGTGCGTTGA & CGGGTCTGATGAAAGTGGTT & 181 & 1.95 \\
\hline CPTIA & FJ415874 & carnitine palmitoyl transferase 1 & TCCTGGTGGGCTACCAATTA & TGCGTCTGTAAAGCAGGATG & 181 & 1.98 \\
\hline CPT2 & NM_001045889 & carnitine palmitoyl transferase 2 & TGTGCCTTCCTTCCTGTCTTGG & CGATGGGGTCTGGGTAAACGA & 111 & 1.89 \\
\hline DGATl & NM_174693.2 & Diacylglycerol O-acyltransferase 1 & CGCCTTCTTCCACGAGTACC & CCGATGATGAGTGACAGCCA & 159 & 1.96 \\
\hline$F A B P 3$ & NM_174313 & fatty acids binding protein 3 & ATCGTGACGCTGGATGGCGG & GCCGAGTCCAGGAGTAGCCCA & 210 & 1.88 \\
\hline FABP5 & NM_174315 & Fatty acid binding protein 5 & TGGCGCATTGGTTCAACATCAGG & TGAACTGAGCTTGTTCATCCTCGC & 193 & 1.90 \\
\hline$F A S N$ & AY343889 & fatty acid synthase & CACTCCATCCTCGCTCTCC & GCCTGTCATCATCTGTCACC & 181 & 1.95 \\
\hline GAPDH & NM_001034034 & glyceraldehyde-3-phosphate dehydrogena & TTCAACGGCACAGTCAAGG & ACATACTCAGCACCAGCATCAC & 119 & 1.95 \\
\hline$N F K B$ & NM_001076409 & $\begin{array}{l}\text { nuclear factor of kappa light polypeptide gene } \\
\text { enhancer in B-cells } 1\end{array}$ & CT & CCATGTCCAGAGGAGTGGTT & 195 & 1.98 \\
\hline PLIN2 & NM_173980 & Perilipine 2 & ACAACACACCССТCAACTGG & CTGCCTGCCTACTTCAGACC & 211 & 1.97 \\
\hline PNPLA2 & NM_001046005 & patatin-like phospholipase dom & ATGGTGCCCTACACTCTGCC & AGCTTCCTCTTGGCGCGTAT & 152 & 2.02 \\
\hline PPARG & Y12419 & $\begin{array}{c}\text { peroxisome proliferator activated receptor } \\
\text { gamma }\end{array}$ & CCCTGGCAAAGCATTTGTAT & ACTGACACCCCTGGAAGATG & 222 & 1.77 \\
\hline PTGS2 & NM_174445 & prostaglandin-endoperoxide synthase 2 & AGGTGTATGTATGAGTGTAGGA & GTGCTGGGCAAAGAATGCAA & 483 & 2.01 \\
\hline RPL19 & BC102223 & Ribosomal protein L19 & AATCGCCAATGCCAACTC & CCCTTTCGCTTACCTATACC & 156 & 1.85 \\
\hline RPS9 & $\mathrm{BC} 148016$ & Ribosomic protein S9 & GGAGACCCTTCGAGAAGTCC & GGGCATTACCTTCGAACAGA & 180 & 1.84 \\
\hline
\end{tabular}




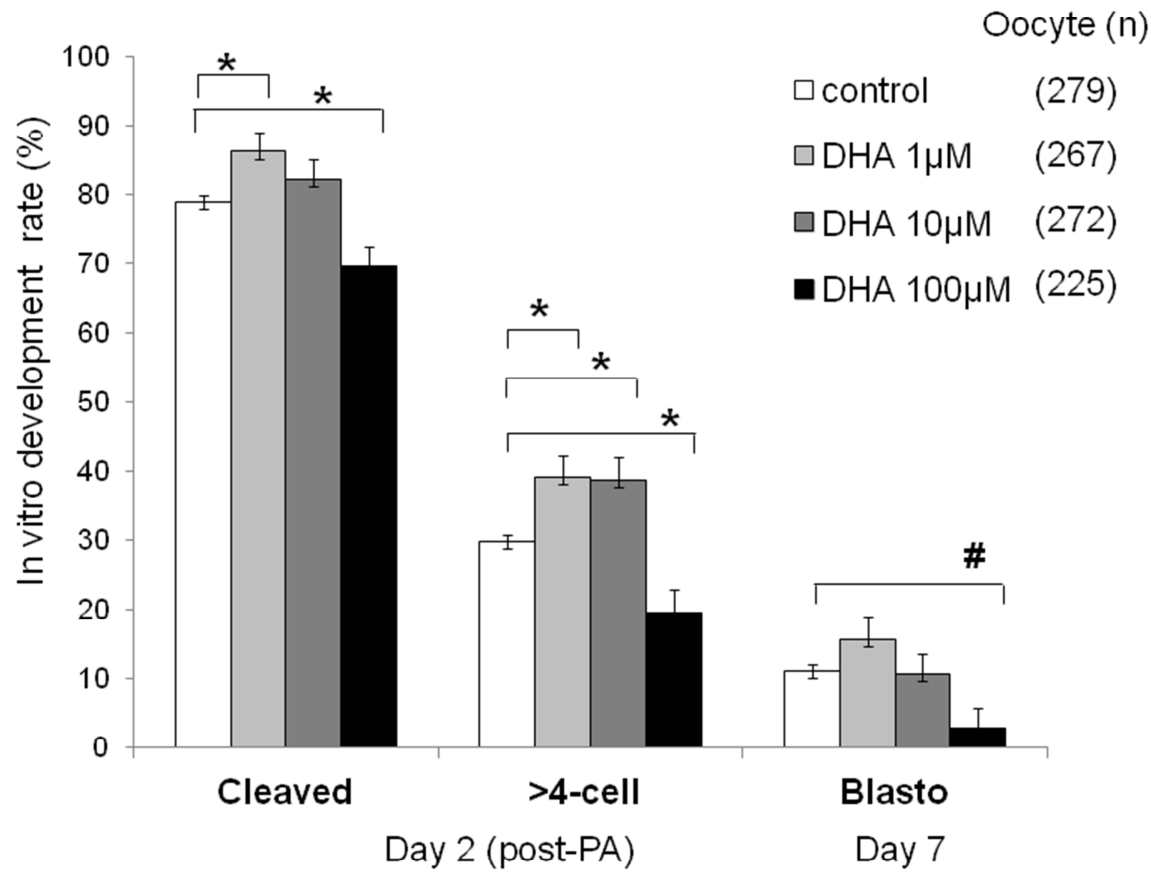


A.

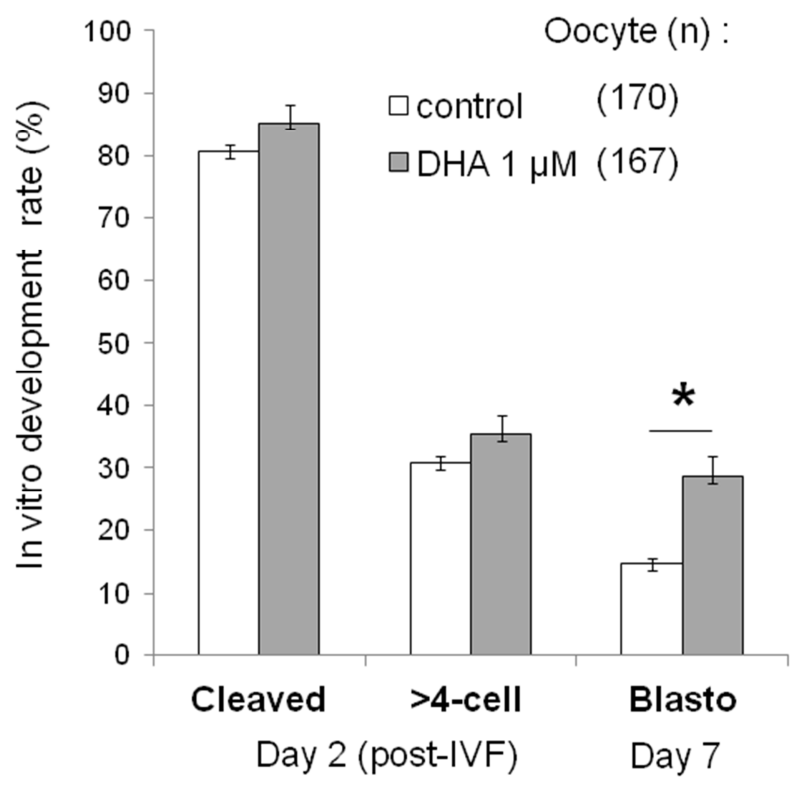

B.

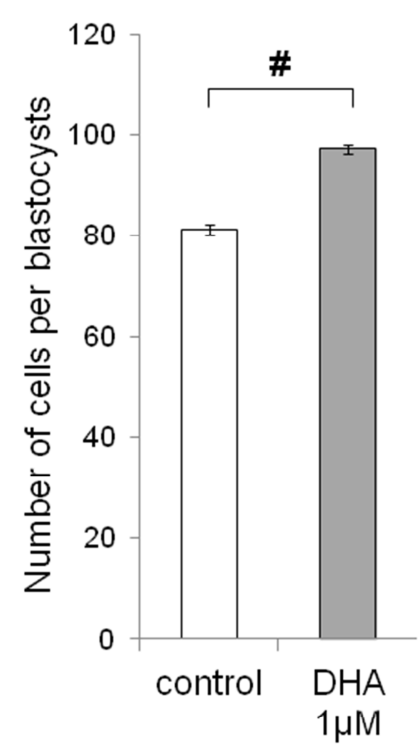


A.

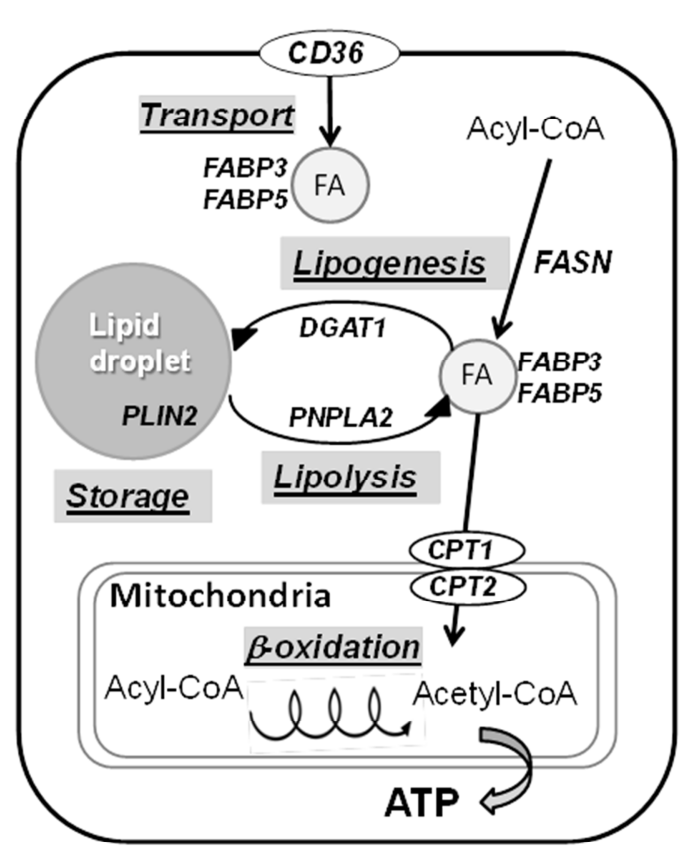

B.
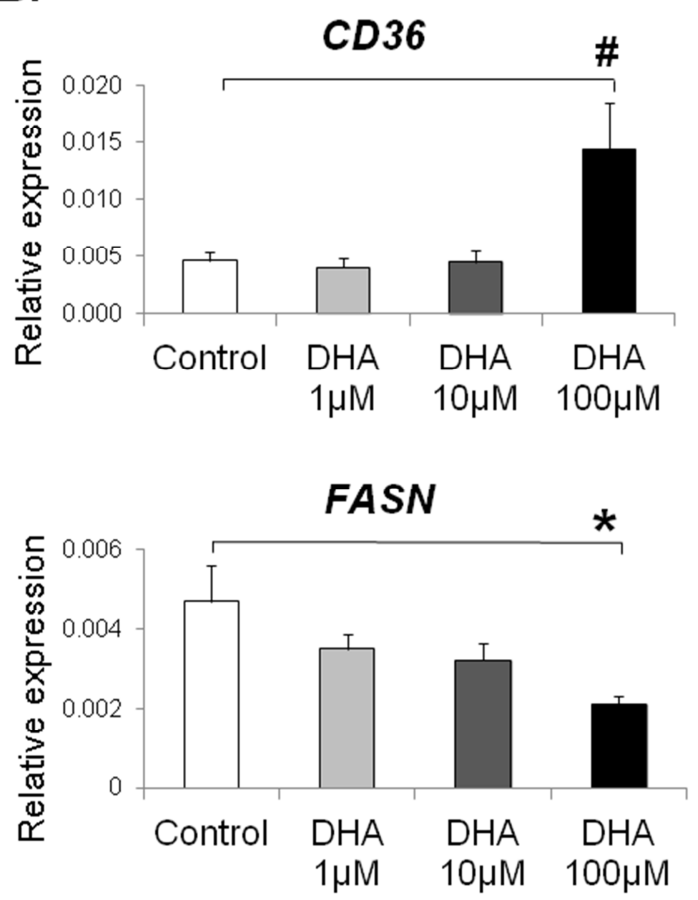


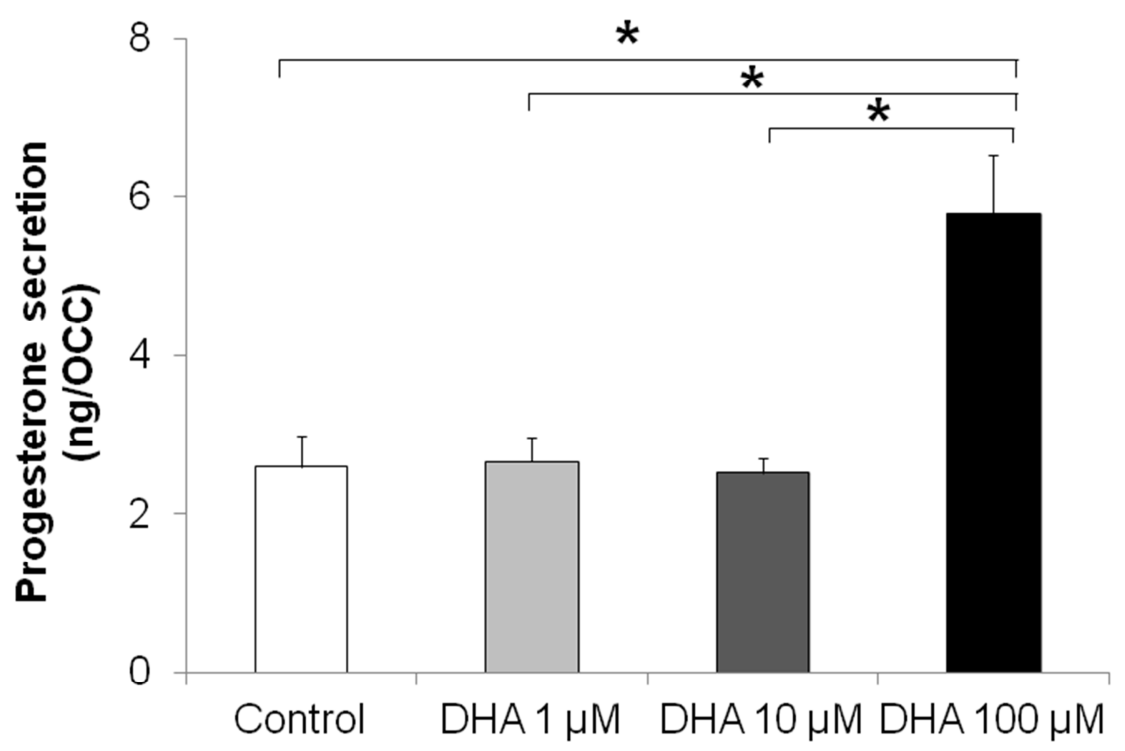




\section{Highlights}

Animal reproductive biotechnologies are required to be more effective in terms of in vitro embryo production. The positive effect of n-3 poly-unsaturated fatty acids (FA) on fertility in ruminants seems to be partly mediated through direct effects on the oocyte developmental potential. We aimed to investigate whether supplementation with physiological levels of docosahexaenoic acid (DHA, C22:6 n-3) during in vitro maturation (IVM) has an effect on oocyte maturation and early embryo development in bovine. We showed that DHA had no effect on oocyte viability or maturation rate after $22 \mathrm{~h}$ IVM with or without 1,10 or $100 \mu \mathrm{M}$ DHA. Incubation of oocyte-cumulus complexes with $1 \mu \mathrm{M}$ DHA during IVM significantly increased oocyte cleavage rate as compared to control and the $>4$-cell embryo rate at day 2 after parthenogenetic activation. Supplementation with $1 \mu \mathrm{M}$ DHA during IVM also induced a significant increase in the blastocyst rate at day 7 after in vitro fertilization as compared to control and tended to increase the number of cells in the blastocysts. On the contrary, $100 \mu \mathrm{M}$ DHA significantly decreased the cleavage rate compared to control and the > 4-cell embryo rate at day 2 after PA. As was shown by real-time PCR, these effects were associated with a three-fold increase in expression level of FA transporter CD36 and a two-fold decrease of FA synthase FASN genes in cumulus cells (CC) of corresponding oocytes, after IVM in the presence of $100 \mu \mathrm{M}$ DHA. Lower DHA concentrations had no effect on expression of those and other key lipid metabolism-related genes in CC. In conclusion, administration of a low physiological dose of DHA $(1 \mu \mathrm{M})$ during IVM may have beneficial effects on oocyte developmental competence in vitro with no effect on nuclear maturation and without affecting lipid metabolism gene expression in surrounding cumulus cells. 
Supplementary Table 1: Effect of DHA during IVM on in vitro embryo development after parthenogenetic activation and in vitro fertilization

\begin{tabular}{|c|c|c|c|c|c|c|c|c|c|c|}
\hline & \multirow{2}{*}{$\begin{array}{l}\text { Control } \\
\% \text { (lsmeans } \pm \\
\text { SEM) }\end{array}$} & \multicolumn{3}{|c|}{ DHA $1 \mu \mathrm{M}$} & \multicolumn{3}{|c|}{ DHA $10 \mu \mathrm{M}$} & \multicolumn{3}{|c|}{ DHA $100 \mu M$} \\
\hline & & $\begin{array}{l}\% \text { (lsmeans } \pm \\
\text { SEM) }\end{array}$ & $\begin{array}{l}\text { Lc } \\
\text { value } \\
\end{array}$ & $\begin{array}{l}\text { gistic regression } \\
\text { OR (CI } 2.5 \%- \\
97.5 \%))\end{array}$ & $\begin{array}{l}\% \text { (lsmeans } \pm \\
\text { SEM) }\end{array}$ & $\begin{array}{l}\text { Lo } \\
\text { p- } \\
\text { value }\end{array}$ & $\begin{array}{l}\text { gistic regression } \\
\text { OR (CI } 2.5 \% \text { - } \\
97.5 \%) \text { ) }\end{array}$ & $\begin{array}{l}\% \text { (lsmeans } \pm \\
\text { SEM) }\end{array}$ & $\begin{array}{l}\text { Log } \\
\text { value }\end{array}$ & $\begin{array}{l}\text { gistic regression } \\
\text { OR (CI } 2.5 \% \text { - } \\
97.5 \%) \text { ) }\end{array}$ \\
\hline \multicolumn{11}{|l|}{ Parthenogenetic activation } \\
\hline Number of oocytes & 279 & 267 & & & 272 & & & 225 & & \\
\hline Cleaved embryo $\%$ & $78.8 \pm 2.5$ & $86.1 \pm 2.1$ & 0.024 & $0.60(0.39-0.93)$ & $82.0 \pm 2.4$ & 0.35 & $0.82(0.54-1.24)$ & $69.5 \pm 3.2$ & 0.017 & $1.63(1.09-2.45)$ \\
\hline $2-4$ cell embryo $\%$ & $44.5 \pm 3.0$ & $43.6 \pm 3.1$ & 0.83 & $1.04(0.74-1.46)$ & $39.6 \pm 3.0$ & 0.25 & $1.22(0.87-1.73)$ & $44.6 \pm 3.4$ & 0.98 & $1.00(0.69-1.43)$ \\
\hline$>4$-cell embryo $\%$ & $29.7 \pm 2.9$ & $39.1 \pm 3.2$ & 0.030 & $0.66(0.45-0.96)$ & $38.7 \pm 3.2$ & $\mathbf{0 . 0 3 7}$ & $0.67(0.46-0.98)$ & $19.5 \pm 2.7$ & 0.012 & $1.74(1.14-2.69)$ \\
\hline$>16$ cell / cleaved embryo $\%$ & $40.0 \pm 4.9$ & $34.1 \pm 4.5$ & 0.38 & $1.28(0.74-2.24)$ & $37.3 \pm 4.5$ & 0.69 & $1.12(0.65-1.94)$ & $13.8 \pm 4.2$ & 0.0004 & $4.15(1.94-9.59)$ \\
\hline Blastocyst / cleaved embryo $\%$ & $11.0 \pm 3.0$ & $15.7 \pm 3.3$ & 0.30 & $0.66(0.30-1.43)$ & $10.7 \pm 2.8$ & 0.95 & $1.03(0.44-2.37)$ & $2.9 \pm 2.2$ & 0.068 & $4.14(1.08-27.19)$ \\
\hline \multicolumn{11}{|l|}{ In vitro fertilization } \\
\hline n oocyte & 170 & 167 & & & & & & & & \\
\hline Cleaved embryo $\%$ & $83.4 \pm 2.9$ & $85.0 \pm 2.8$ & 0.68 & $0.88(0.49-1.59)$ & & & & & & \\
\hline $2-4$ cell embryo $\%$ & $49.4 \pm 3.9$ & $49.8 \pm 3.9$ & 0.88 & $0.97(0.63-1.49)$ & & & & & & \\
\hline$>4$-cell embryo $\%$ & $33.2 \pm 3.6$ & $34.0 \pm 3.7$ & 0.87 & $0.96(0.61-1.52)$ & & & & & & \\
\hline Blastocyst / cleaved embryo \% & $17.6 \pm 3.3$ & $30.6 \pm 4.1$ & 0.013 & $0.48(0.27-0.85)$ & & & & & & \\
\hline
\end{tabular}

P-values different from the control at $\mathrm{p}<0.05$ are in bold, $\mathrm{p}$-values different from the control with $\mathrm{p} \geq 0.05$ and $\mathrm{p}<0.1$ are in italics. OR: odds ratio, CI: confidence interval

\section{Supplementary Table 2: Effect of DHA during IVM on oocyte nuclear maturation}




\begin{tabular}{|c|c|c|c|c|c|c|c|c|c|c|}
\hline & \multicolumn{2}{|l|}{ Control } & \multicolumn{2}{|c|}{ DHA $1 \mu \mathrm{M}$} & \multicolumn{3}{|c|}{ DHA $10 \mu \mathrm{M}$} & \multicolumn{3}{|c|}{ DHA $100 \mu \mathrm{M}$} \\
\hline & $\begin{array}{l}\% \text { (lsmeans } \pm \\
\text { SEM) }\end{array}$ & $\begin{array}{l}\% \text { (lsmeans } \pm \\
\text { SEM) }\end{array}$ & $\begin{array}{l}\mathrm{L} \\
\mathrm{p}- \\
\text { value }\end{array}$ & $\begin{array}{l}\text { gistic regression } \\
\text { OR (CI 2.5\% - } \\
97.5 \%))\end{array}$ & $\begin{array}{l}\% \text { (lsmeans } \pm \\
\text { SEM) }\end{array}$ & $\begin{array}{l}\text { Lo } \\
\text { p- } \\
\text { value }\end{array}$ & $\begin{array}{l}\text { gistic regression } \\
\text { OR (CI } 2.5 \% \text { - } \\
97.5 \%) \text { ) }\end{array}$ & $\begin{array}{l}\% \text { (lsmeans } \pm \\
\text { SEM) }\end{array}$ & $\begin{array}{l}\text { Lo } \\
\text { value } \\
\end{array}$ & $\begin{array}{l}\text { gistic regression } \\
\text { OR (CI } 2.5 \% \text { - } \\
97.5 \%))\end{array}$ \\
\hline \multicolumn{11}{|l|}{ In vitro maturation } \\
\hline Number of oocytes & 136 & 152 & & & 119 & & & 100 & & \\
\hline immature $\%$ & $3.1 \pm 1.5$ & $2.8 \pm 1.4$ & 0.89 & $1.09(0.30-4.02)$ & $3.5 \pm 1.7$ & 0.85 & $0.88(0.24-3.27)$ & $2.6 \pm 1.6$ & 0.82 & $1.19(0.28-5.96)$ \\
\hline Meta-1\% & $11.3 \pm 2.7$ & $12.8 \pm 2.7$ & 0.70 & $0.87(0.42-1.76)$ & $9.1 \pm 2.7$ & 0.56 & $1.28(0.57-2.95)$ & $8.3 \pm 2.7$ & 0.43 & $1.42(0.61-3.50)$ \\
\hline Ana-1 $\%$ & $1.5 \pm 1.1$ & $4.6 \pm 1.7$ & 0.15 & $0.31(0.05-1.30)$ & $2.5 \pm 1.5$ & 0.55 & $0.58(0.08-3.56)$ & $4.0 \pm 2.1$ & 0.24 & $0.36(0.05-1.87)$ \\
\hline Telo-1\% & $5.0 \pm 1.9$ & $1.8 \pm 1.1$ & 0.15 & $2.77(0.75-13.09)$ & $1.6 \pm 1.2$ & 0.15 & $3.24(0.76-22.09$ & $14.0 \pm 3.6$ & $\mathbf{0 . 0 2 0}$ & $0.32(0.12-0.81)$ \\
\hline Meta- $2 \%$ & $78.1 \pm 3.5$ & $77.0 \pm 3.4$ & 0.83 & $1.06(0.61-1.86)$ & $82.4 \pm 3.5$ & 0.39 & $0.76(0.40-1.41)$ & $70.4 \pm 4.6$ & 0.18 & $1.50(0.83-2.71)$ \\
\hline mature $\%$ & $83.5 \pm 3.2$ & $79.2 \pm 3.3$ & 0.35 & $1.33(0.74-2.44)$ & $84.3 \pm 3.3$ & 0.87 & $0.95(0.48-1.84)$ & $84.7 \pm 3.6$ & 0.80 & $0.91(0.45-1.83)$ \\
\hline
\end{tabular}

Oocyte meiotic stages were assessed after IVM with or without DHA $(1 \mu \mathrm{M}, 10 \mu \mathrm{M}$ or $100 \mu \mathrm{M})$. Five meiotic stages were differentiated: prophase oocytes at germinal vesicle (GV), GV breakdown, metaphase-I (Meta-I), and anaphase-I (Ana-I) and telophase-I (Telo-I) and metaphase -II (Meta-II). Results of three independent experiments are expressed as the lsmeans percentage of oocytes in each meiotic stage \pm SEM. P-values different from the control at $p<0.05$ are in bold, $p$-values different from the control with $p \geq 0.05$ and $p<0.1$ are in italics. OR: odds ratio, CI: confidence interval 
Supplementary Table 3: Effect of DHA on gene expression in cumulus cells

\begin{tabular}{lllll}
\hline & Control & DHA $1 \mu \mathrm{M}$ & DHA $10 \mu \mathrm{M}$ & DHA $100 \mu \mathrm{M}$ \\
\hline FASN & $1.00 \pm 0.19$ & $0.74 \pm 0.08$ & $0.69 \pm 0.09$ & $\mathbf{0 . 4 4} \pm \mathbf{0 . 0 5}$ \\
DGAT1 & $1.00 \pm 0.37$ & $0.76 \pm 0.15$ & $0.85 \pm 0.30$ & $0.45 \pm 0.12$ \\
PLIN2 & $1.00 \pm 0.07$ & $0.62 \pm 0.23$ & $0.95 \pm 0.18$ & $1.39 \pm 0.49$ \\
CPT1A & $1.00 \pm 0.16$ & $1.07 \pm 0.15$ & $0.80 \pm 0.14$ & $1.16 \pm 0.18$ \\
CPT2 & $1.00 \pm 0.16$ & $0.89 \pm 0.12$ & $0.74 \pm 0.12$ & $0.85 \pm 0.07$ \\
PNPLA2 & $1.00 \pm 0.19$ & $1.01 \pm 0.37$ & $0.41 \pm 0.07$ & $0.49 \pm 0.12$ \\
FABP3 & $1.00 \pm 0.13$ & $0.61 \pm 0.16$ & $0.70 \pm 0.15$ & $0.64 \pm 0.10$ \\
FABP5 & $1.00 \pm 0.36$ & $0.56 \pm 0.19$ & $1.59 \pm 0.98$ & $3.70 \pm 1.81$ \\
CD36 & $1.00 \pm 0.17$ & $0.86 \pm 0.19$ & $0.97 \pm 0.23$ & $3.09 \pm \mathbf{0 . 8 8}$ \\
NFKB & $1.00 \pm 0.20$ & $0.95 \pm 0.11$ & $0.93 \pm 0.12$ & $0.93 \pm 0.22$ \\
PTGS2 & $1.00 \pm 0.36$ & $0.83 \pm 0.27$ & $1.15 \pm 0.34$ & $0.64 \pm 0.15$ \\
PPARG & $1.00 \pm 0.04$ & $1.13 \pm 0.22$ & $0.93 \pm 0.19$ & $0.84 \pm 0.23$ \\
\hline Cumulus & Cex & &
\end{tabular}

Cumulus cell gene expression was assessed after $22 \mathrm{~h} \mathrm{IVM} \mathrm{of} \mathrm{DHA} \mathrm{treatment.} \mathrm{Genes} \mathrm{involved} \mathrm{in} \mathrm{lipid} \mathrm{metabolism} \mathrm{(FASN,} \mathrm{DGAT1,} \mathrm{PLIN2,}$ $C P T 1 A, C P T 2$, PNPLA2, FABP3, FABP5 and CD36) and three genes potentially involved in DHA action pathways (NFKB, PTGS2 and PPARG) were analyzed. The geometric mean of three housekeeping genes (RPL19, RPS9 and GAPDH) was used to normalize gene expression. Results of five independent cultures with each condition in duplicate are presented as means \pm SEM. Values in bold indicate significant difference for a given stage compared to the control $(p<0.05)$. P-value $(0.05<\mathrm{p}<0.1)$ indicates a tendency compared to the control and expression value is in italic. 